\title{
CHAOS, MORAL DECADENCE, AND BETRAYAL (SATIRE IN "DI TEPI KALI BEKASI" NOVEL BY PRAMOEDYA ANANTA TOER)
}

\author{
Rudy Gunawan ${ }^{1}$, Desvian Bandarsyah ${ }^{2}$, dan Wildan Insan Fauzi ${ }^{3}$ \\ ${ }^{1,2}$ Universitas Muhammadiyah Prof. Dr. Hamka \& ${ }^{3}$ Universitas Pendidikan \\ Indoneisa \\ email: rudyansich@gmail.com
}

\begin{abstract}
Indonesian revolution in 1945-1949 is a remarkable moment for all of Indonesian people which is full of heroic spirit. Interestingly, Pramoedya portrayed the revolution moment in a novel entitled "Di Tepi Kali Bekasi" with different point of view in which he used a sarcasm style of language to depict the conditions and deliver his critics about people's behaviors from various clusters at that time. Therefore, this current study is motivated by interest to explore how satirical narrative is used in the novel. A qualitative content analysis with context unit model was employed as a research method to describe and analyze in detail the description and characteristics of satire in the novel. Specifically, a concept of satire intended in this study is focused on sarcasm, social criticism, and irony. Based on the results of analysis, there are some satirical elements in the novel namely social chaos (chaos), public unrest, bandits and robbery, betrayal, generation conflicts, youth nationalism, and immoral behavior and corruption of the army. In addition, according to Pramoedya's view, revolution is considered as a bestiality period where the revolution of soul is more important and needed by the nation instead of the army revolution. Due to those facts, independence was still considered as a fake independence where unheard voice of the periphery and moral destruction were still the main problem in the society. Generally, it is found that the satirical root in the novel is laid on two things namely Pramoedya's direct experience as a soldier and his imaginations conveyed in the novel.
\end{abstract}

Keywords: Di Tepi Kali Bekasi, historical novel, Pramoedya Ananta Toer, satire

\section{CHAOS, DEKANDENSI MORAL, DAN PENGKHIANATAN (SATIR DALAM NOVEL DI TEPI KALI BEKASI KARYA PRAMOEDYA ANANTA TOER)}

\begin{abstract}
Abstrak
Revolusi fisik 1945-1949 merupakan periode yang disakralkan dan digambarkan penuh dengan semangat kepahlawanan. Namun, Pramoedya menggambarkan revolusi Indonesia dalam novel di Tepi kali Bekasi dengan gaya bahasa satir yang berisi kritikan tajam dan ironi terhadap perilaku berbagai kalangan. Tujuan penelitian ini adalah mendeskripsikan narasi satir dalam novel Di Tepi Kali Bekasi karya Pramoedya Ananta Toer. Penelitian ini menggunakan metode analisis isi kualitatif untuk menggambarkan dan menganalisis secara detail deskripsi dan
\end{abstract}


karakteristik satir dalam novel. Analisis data yang digunakan adalah unit konteks. Konsep satir yang dimaksud adalah sindiran, kritik sosial, dan ironi. Unsur satir yang terdapat dalam novel adalah kekacauan sosial (chaos), keresahan masyarakat, bandit dan rampok, pengkhianatan, konflik generasi, nasionalisme pemuda, serta perilaku amoral dan korupsi tentara. Cara pandang Pramoedya mengenai revolusi adalah revolusi sebagai zaman kebinatangan, revolusi jiwa lebih berhasil daripada revolusi bersenjata, kemerdekaan hanya kemerdekaan semu, suara kaum pinggiran, dan kehancuran moral. Akar satir dalam novel Di Tepi Kali Bekasi bertumpu pada dua hal, yaitu pengalaman langsung Pramoedya sebagai tentara dan gagasan-gagasan yang ingin disampaikannya dalam novel.

Kata kunci: Di tepi kali bekasi, novel sejarah, Pramoedya Ananta Toer, Satir

\section{PENDAHULUAN}

Revolusi merupakan kisah sentral dalam sejarah Indonesia dan merupakan unsur yang sangat kuat dalam persepsi bangsa Indonesia tentang dirinya sendiri. Meskipun dalam kajiankajian sejarah digambarkan konflik dan kekerasan yang muncul dalam dinamika revolusi, namun bangsa Indonesia dalam romantisme sejarah mengenang dan menganggapnya sebagai periode yang sakral. Konsep "semangat 45" menggambarkan dengan jelas betapa periode revolusi fisik 1945-1949 merupakan periode yang digambarkan penuh dengan semangat kepahlawanan (Ricklefs, 2005).

Namun, hal tersebut nampaknya tidak akan ditemukan dalam novel Di Tepi Kali Bekasi karya Pramoedya Ananta Toer. Pramoedya menggambarkan revolusi Indonesia dalam gaya bahasa satiryang penuh dengan kritikan tajam terhadap perilaku berbagai kalangan yang terlibat dalam proses revolusi tersebut. Novel Di Tepi Kali Bekasi menggambarkan banyak ironi dalam kelompok-kelompok masyarakat Indonesia sehingga revolusi Indonesia sepertinya jauh dari kesan kepahlawanan dan nasionalisme. Satir adalah gaya bahasa yang menyatakan sindiran terhadap suatu keadaan (Prasetoyono, 2011). Gaya bahasa satir berisi kritik sosial baik secara terang-terangan maupun terselubung (Murti, 2013).

Memang benar, penulisan novel ini bertujuan untuk mengenangkan masamasa revolusi dimana para pemuda berjuang dengan gagah perwira melawan tentara Sekutu dan Belanda (Gunawan, 2017). Namun, tema yang mengalir dalam novel ini selain berkisah tentang keberanian dan ketulusan, malah mayoritas berkisah tentang kepengecutan, perselingkuhan, benturan kepentingan antara kaum tua dan kaum muda, serta konflik sosial (Gunawan, 2017).

Novel Di Tepi Kali Bekasi bergenre novel sejarah. Novel sejarah dalam banyak kasus biasa memberikan perspektif yang berbeda tentang sejarah dengan apa yang biasa diungkap sejarawan. Novel sejarah merupakan roman yang menceritakan suatu masa dalam sejarah dan mencoba menampilkan dan menangkap semangat zaman (zeitgeist) masa lampau dengan menguraikan secara detil fakta historis sehingga terkesan realistis (Lindquist, 2008). Ketika 
membaca novel Di Tepi Kali Bekasi, pembaca akan larut dalam suasana revolusi Indonesia yang penuh emosi beserta kengerian perang yang menyertainya. Meskipun pembaca juga akan dihibur oleh kelucuan, satir, dan romantisme tokoh-tokoh utamanya.

Novel-novel Pramoedya sangat menarik jika dikaji karena didalamnya sebagian besar menampilkan kolonialisme, nasionalisme, dan berbagai konflik yang ditimbulkannya. Kajian unsurunsur satir dalam novel ini memberikan sudut pandang yang berbeda bagi pembaca dalam melihat revolusi di Indonesia. Novel-novel sejarah dapat membantu sejarawan dan pendidik sejarah dalam mengisi kekurangan dalam menggali fakta fakta sosial atau faktafakta mental yang tidak terekam dalam sumber-sumber dokumen (Bangsawan, 2017).

Setiap novelis memotret dan memaknai kehidupan di sekitarnya untuk kemudian diekspresikan melalui karya sastra. Adanya satir dalam novel $D i$ Tepi Kali Bekasi memperlihatkan sastra mengandung perasaan atau emosi dari sudut pandang penulis. Kajian novel sejarah dari aspek perspektif penulis perlu dilakukan agar pembaca memahami cara pandang pengarang pada realitas tertentu dan dalam upaya memahami kandungan makna dalam suatu cipta sastra (Aminuddin, 2009).

Riset-riset tentang novel-novel Pramoedya sudah banyak dilakukan.Tahun 1995, Teuw mengkaji novel Keluarga Geriliya dan pada 1997 mengkaji ideologi nasionalisme pada karya-karya Pramoedya. Dalam artikelnya, Teeuw mengkaji juga novel Di Tepi Kali Bekasi. Dalam kajiannya, Teeuw melihat nasionalisme hanyalah milik anak-anak muda sementara generasi tua tidak ada tempat di Revolusi Indonesia karena mereka sudah terkontaminasi kolonialisme. Rangkuti (1963), Aveling (1975) dan Vickers (2013) melakukan riset tentang masa muda Pramoedya dan pengaruhnya pada novel-novelnya.

Niekerk (2017) meneliti aspek postkolonial novel Gadis Pantai. Niekerk melihat novel tersebut mengkritik struktur kekuasaan sebelum dan sesudah Indonesia merdeka. Kajian Niekerk mirip dengan riset Dewi (2007) yang meneliti aspek postkolonial dari novel Gadis Pantai dan Larasati. Dewi (2007) berkesimpulan bahwa tokoh-tokoh dalam kedua novel tersebut memiliki suara otonom yang tidak dapat digeneralisasi dalam suara perempuan di dunia ketiga pada umumnya. Raybin (2009) mengkaji juga novel Gadis Pantai. Raybin melihat karya Pramoedya tersebut paralel dengan novel Clerk's Tale karya Chaucer, yang sama-sama membahas hubungan perkawinan dalam masyarakat patriarki postkolonial.

Graf (2007) melakukan riset mengenai persepsi dunia maya terhadap karya-karya Pramoedya. Hasil risetnya menyatakan bahwa karya Pramoedya yang paling popular di dunia maya adalah novel Bumi Manusia. Terdapat lima persepsi warganet mengenai novel Pramoedya, yaitu, sejarah era kolonial, wacana tentang identitas timur/barat, simpati untuk penulis yang diasingkan dan dipenjara, konteks ideologis Era Perang Dingin, dan apresiasi plot sebagai kisah cinta serta hubungan gender. Herriman (2010) mengkaji novel Perburuan. Perburuan berlatar kota Blora yang merupakan tempat kelahiran Pramoedya dan memiliki sejarah panjang perlawanan. Novel ini bercerita 
tentang akhir pendudukan Jepang di Indonesia tahun 1945.

Tsao (2012) mengkaji empat novel tetralogi pulau Buru, yaitu Bumi Manusia, Anak Semua Bangsa, Jejak Langkah, dan Rumah Kaca. Tsao menilai bahwa novel-novel tersebut menggambarkan pertautan nilai-nilai tradisional Jawa masa kecil Pramoedya dan nilai-nilai ideologis Marxis ketika Pram dewasa. Kajian Bostock (2017) berfokus pada hubungan ayah dan anak pada beberapa novel Pramoedya, yaitu Bukan Pasar malam, Cerita dari Blora, dan Bumi Manusia. Analisa Bostock memperlihatkan bahwa hubungan yang rumit dan penuh konflik antara ayah dan anaknya dalam novel-novel tersebut mengambarkan kehidupan riil dari Pramoedya dan ayahnya itu sendiri. Nampaknya kesimpulan Bostock tersebut dapat dikaitkan juga dengan novel Di Tepi kali bekasi, karena didalamnya tedapat hubungan konflik antara Farid dan ayahnya yang mantan anggota KNIL. Kajian Tsao (2012) dan Bostock (2017) menunjukan bahwa karya-karya Pramoedya sangat terkait dengan kehidupannya itu sendiri.

Penelitian ini berbeda dari kajian riset-riset sebelumnya tentang novel Pramoedya karena berfokus pada unsur satir. Dengan demikian, kajian novel ini akan menganalisis unsur satir, sudut pandang pengarang, dan juga akan mengkaji faktor-faktor apa saja yang menjadi penyebab pengarang menonjolkan unsur satir tersebut.

Berdasarkan latar belakang masalah tersebut, tujuan penelitian ini adalah mendeskripsikan narasi satir dalam novel Di Tepi Kali Bekasi karya Pramoedya Ananta Toer.Atas dasar masalah tersebut, kemudian dibuat rumusan masalah dalam bentuk pertanyaan penelitian yang meliputi pertama, unsur-unsur satir apa saja yang dideskripsikan dalam novel Di Tepi Kali Bekasi; kedua, cara pandang satir Pramoedya Ananta toer tentang revolusi Indonesia 1945-1949 pada novel Di Tepi kali Bekasi; ketiga, faktor-faktor yang memengaruhi unsur satir pada novel Di Tepi kali Bekasi.

\section{METODE}

Penelitian ini menggunakan metode analisis isi kualitatif (qualitative content analysis). Pengertian pendekatan analitis itu sendiri adalah suatu pendekatan yang berusaha memahami gagasan, cara pengarang menampilkan gagasan atau mengimajikan ide-ide, serta sikap pengarang dalam menampilkan gagasan-gagasannya (Aminuddin, 2009). Analisis naratif adalah analisis mengenai narasi baik fiksi (novel sejarah) maupun fakta dalam tulisan sejarawan (Eriyanto, 2015). Analisis isi digunakan untuk mengkaji kekuatan sosial politik yang dominan dan bekerja dalam teks sastra, serta nilai-nilai yang ditonjolkan oleh novelis (Eriyanto, 2013).

Penelitian ini mengkaji unsur-unsur satir pada novel Di Tepi Kali Bekasi. Analisis isi digunakan untuk menggambarkan secara detail deskripsi dan karakteristik satir dalam novel. Sumber data yang digunakan dalam penelitian ini, yaitu novel Ditepi Kali Bekasi karya Pramoedya Ananta Toer. Data yang digunakan dalam penelitian ini adalah informasi-informasi yang berupa kalimat, percakapan, dan penggalan paragraf yang menunjukkan tentang unsur satir dalam novel Di Tepi Kali Bekasi. Dari sumber data penelitian, diperoleh informasi data atau fakta verbal yang berupa percakapan dan penggalan paragraf. 
Desain penelitian ini tidak dimaksudkan untuk menguji suatu hipotesis tertentu atau menguji hubungan antar variabel melainkan analisis isi deskriptif yang dimaksudkan untuk menggambarkan dan mengungkap secara detail narasi satir pada novel Di Tepi Kali Bekasi (Eriyanto, 2015). Tabel 1 berisi gambaran desain analisa unsur satir dalam novel Di Tepi Kali Bekasi.

Unit analisis data yang digunakan adalah unit konteks. Dalam hal ini, konsep satir yang dimaksud adalah sindiran terhadap suatu keadaan, kritik sosial baik secara terang-terangan maupun terselubung, serta unsur Ironi. Mengkritik merupakan sifat menilai suatu keadaan dengantujuan untuk memperbaiki dan membangun lebih baik sementara ironi adalah majas yang menyatakan makna yang bertentangan dengan maksud mengolok-olok.

\section{HASIL DAN PEMBAHASAN}

\section{Hasil}

\section{Kekacauan Masa Revolusi}

Masa revolusi, daerah Bekasi menjadi sebuah daerah pertahanan yang menjadi momok baik pihak Inggris dan Belanda. Dengan adanya perlawanan dari pihak Bekasi maka terjadi serang- menyerang terhadap pihak Sekutu. Pertempuran-pertempuran tersebut meliputi daerah Cakung, Teluk Pucung, Cileungsi, Tambun, Bekasi, dan Penggarutan. Tabel 2 memperlihatkan gaya bahasa satir mengenai kekacauan selama revolusi.

Novel Di Tepi Kali Bekasi menggambarkan situasi tertib sosial yang kacau dan anomi selama masa revolusi. Novel ini bercerita tentang kondisi masyarakat yang kesulitan pasca lepas dari penjajahan Jepang. Masyarakat Bekasi pada waktu itu digambarkan penuh dengan kekhawatiran pada tentara NICA dan Inggris (Toer, 1995: 181). Pramoedya menyebutkan bahwa setelah pembakaran Bekasi oleh tentara Inggris India, rakyat Bekasi jadi rakyat liar, lekas kaget, dan takut, lebih-lebih terhadap orang bersenjata, sebab dikiranya tentulah NICA (Toer, 1995: 61). Secara psikologis, tidak ada heroisme yang digambarkan Pramoedya, hanya masyarakat Bekasi yang jadi paranoid akibat peristiwa pembakaran Bekasi. Hal negatif inilah yang sering diungkap oleh Pramoedya, revolusi melahirkan orang-orang yang tidak waras dan terganggu secara psikologi.

Tabel 1. Desain Analisis Isi Novel di Tepi Kali Bekasi

\begin{tabular}{|c|c|c|c|c|c|}
\hline \multirow[b]{2}{*}{ No. } & \multirow[b]{2}{*}{ Unsur yang Dikaji } & \multicolumn{2}{|c|}{ Unsur Satir } & \multirow{2}{*}{$\begin{array}{l}\text { Cara Pandang } \\
\text { Pengarang }\end{array}$} & \multirow{2}{*}{$\begin{array}{c}\text { Faktor } \\
\text { Penyebab }\end{array}$} \\
\hline & & $\begin{array}{l}\text { Sindiran dan } \\
\text { Kritik Sosial }\end{array}$ & Ironi & & \\
\hline 1 & Chaos dan Revolusi & & & & \\
\hline 2 & Bandit dan Rampok & & & & \\
\hline 3 & Revolusi dan Pengkhianatan & & & & \\
\hline 4 & Konflik Generasi & & & & \\
\hline 5 & Nasionalisme, Pemuda dan Jawara & & & & \\
\hline 6 & Moral Tentara. & & & & \\
\hline
\end{tabular}


Tabel 2. Satir mengenai Chaos dan Revolusi

\begin{tabular}{|c|c|c|}
\hline Narasi Novel tentang Chaos dan Revolusi & Unsur Satir & Halaman \\
\hline $\begin{array}{l}\text { "Penjual-penjual di Pasar Nangka seorang demi } \\
\text { seorang mengangkut dagangannya pulang kembali" }\end{array}$ & $\begin{array}{l}\text { Revolusi "mengganggu" } \\
\text { kegiatan ekonomi } \\
\text { masyarakat }\end{array}$ & 7 \\
\hline $\begin{array}{l}\text { "Nah, terpaksa saya menjual kaus biruku yang sangat } \\
\text { saya cintai waktu itu. Sekarang apa jadinya? .... } \\
\text { Sekolah tidak, uang terbuang. Pakaian hilang entah } \\
\text { kemana perginya. Nasib buruk........" }\end{array}$ & hidup melarat masa revolusi & 14 \\
\hline $\begin{array}{l}\text { "Setelah pembakaran bekasi oleh tentara Inggris india, } \\
\text { rakyat bekasi jadi rakyar yang liar. Lekas kaget dan } \\
\text { takut ......sebab dikiranya tentulah NICA inlander" }\end{array}$ & $\begin{array}{l}\text { rakyat Bekasi yang agresif } \\
\text { dan paranoid }\end{array}$ & 61 \\
\hline $\begin{array}{l}\text { "Rakyat Bekasi ingat selalu bagaimana serdadu- } \\
\text { serdadu Sikh yang kejam seram itu menembaki laki } \\
\text { perempuan" }\end{array}$ & Kekejaman tentara sekutu & 61 \\
\hline $\begin{array}{l}\text { "...di pasar Cakung yang dilihatnya hanyalah bangkai } \\
\text { perabot warung saja. Sebulan yang lalu pasar ini } \\
\text { dibongkar oleh musuh...." }\end{array}$ & $\begin{array}{l}\text { Revolusi "mengganggu" } \\
\text { kegiatan ekonomi } \\
\text { masyarakat }\end{array}$ & 134 \\
\hline $\begin{array}{l}\text { "...dipinggir sawah tampak kawat tilpun berantakan } \\
\text { putus-putus kawat yang memhubungkan Cilincing } \\
\text { dengan Bekasi. Sawah-sawah yang tak ditanami } \\
\text { digenani air rawa" }\end{array}$ & $\begin{array}{l}\text { Revolusi membuat sawah- } \\
\text { sawah terbengkalai }\end{array}$ & 135 \\
\hline
\end{tabular}

Keadaan sosial pada saat itu memang tidak menentu, dimana terjadinya carut marut keadaan karena kedatangan bangsa asing yang ingin menjajah lagi Indonesia. Novel menceritakan kehidupan masyarakat yang serba susah dan melarat dalam situasi revolusi Indonesia, termasuk kesulitan para pegawai, pedagang, penjahit, dan berbagai profesi lainnya. Kesulitan ekonomi inilah yang menjadi salah satu penyebab munculnya kejahatan dan perampokan di Jakarta, Bekasi, dan sekitarnya (Toer, 1995: 14).

Novel mendeskripsikan kehancuran ekonomi masyarakat yang disebabkan hancurnya pasar setelah dibakar oleh tentara Sekutu. Selain itu, novel juga menguraikan bagaimana sawah-sawah masa perang terbengkalai. Hal tersebut menjadi pemandangan lumrah di In- donesia pada masa revolusi. Keadaan ekonomi yang memprihatinkan karena $t$ termasuk juga para tentara yang bahkan demi mendapatkan makanan, tentara menukar durian dengan granat yang mereka miliki (Toer, 1995: 14). Dampak perang memang sangat terasa pada kondisi pasar yang tidak menentu dan penuh dengan ketakutan serta kekhawatiran. Pedagang mencoba beradaptasi dengan menyiapkan diri menghadapi kondisi terburuk. Mereka sudah mempersiapkan segala sesuatunya termasuk barang dagangannya kalau tibatiba perang pecah, mereka sudah siap untuk segera pulang ke rumah (Toer, 1995: hal. 7). Novel menguraikan juga tentang pekerjaan masyarakat Jakarta waktu itu. Misalnya penjahit yang sedang kebanjiran order karena pasokan bahan pakaian yang banyak. Selain itu, 
ada pekerjaan tukang kebun di kantor radio dengan gaji tiga puluh rupiah (Toer, 1995: 45).

Pramoedya banyak mendeskripsikan tentang kekejaman-kekejaman selama perang, baik itu yang dilakukan oleh Jepang, Sekutu, maupun oleh tentara Republik itu sendiri. Pembakaran kota Bekasi, kekejaman tentara Sikh India, perilaku tentara NICA yang suka merampas barang-barang penduduk diuraikan dengan emosional oleh Pramoedya. Dari sini nampaklah bahwa kejadian-kejadian tersebut dilihat secara langsung oleh penulis novel sehingga membawa kesan emosi yang mendalam.

Kekejaman perang kelihatannya menjadi sorotan Pramoedya dalam novelnya. Novel juga mengisahkan keadaan pasca proklamasi kemerdekaan Indonesia. Beberapa bulan setelah proklamasi kemerdekaan, seorang kapten TKR (Tentara Keamanan Rakyat) dengan bantuan duabelas prajuritnya membinasakan satu seksi pasukan Jepang yang hendak mengacau daerah Bekasi. Bangkai-bangkai jepang itu terpaksa terapung di daratan air kali bekasi. Oleh kemenangan itu,TKR dapat memperoleh limapuluh karabin jepang dengan dua senapan-mesin berat serta ringan dan beribu-ribu peluru (Toer, 1995:4). Dalam satir, ini adalah ironi karena prajurit Indonesia yang dibanggakan juga ternyata bisa menjadi "penjagal".

Revolusi digambarkan dengan pengalaman yang penuh dengan kengerian dan menyeramkan (Toer, 1995: 1). Pertempuran di Kranji yang membuat suasana di markas menjadi mencekam dan penduduk sekitar menjadi ketakutan (Toer, 1995: 184). Dentam peluru dan artileri terdengar di Kranji, Bojong Rangkong terdesak, meriam ditembakkan dari Kranji ke Bojong Rangkong. Houwitzer yang sudah diperbaiki menembaki musuh yang mendesak dari Cakung. Seorang rakyat yang teriris pahanya oleh pecahan mortir dibawa Palang Merah (Toer, 1995: 184).

Jadi secara satir Pramoedya mengambarkan kepada pembacanya bahwa revolusi hanya melahirkan sifat masyarakat yang agresi dan terganggu secara psikologis, paranoid tata terbit sosial yang hancur, kekejaman perang, ekonomi yang hancur, kemelaratan, korban yang berjatuhan dan kesulitan hidup yang lainnya. Jadi apa yang bisa dibanggakan dalam revolusi 1945 ?

\section{Bandit}

Kekacauan sosial masa revolusi diperlihatkan dengan banyaknya bandit (perampok) yang berkeliaran memanfaatkan situasi tersebut. Rakyat Bekasi sejak dahulu terpaksa bersatu untuk menangkis serangan perampok yang tidak kenal akan keadilan dan kemanusiaan (Toer, 1995:11). Tabel 3 memperlihatkan satir mengenai rampok di novel yang dimaksud.

Keadaan para perampok di Bekasi digambarkan sebagai sosok yang kasar (Toer, 1995: 88). Namun yang menarik, para perampok atau garong tersebut selain digambarkan kasar dan kejam, diuraikan pula bahwa mereka bukan hanya orang jahat yang mengambil keuntungan disituasi yang kacau, namun juga kelompok yang sengaja diciptakan oleh Belanda untuk kepentingan politiknya (Toer, 1995:5). Ironi nampak dalam uraian Pramoedya bahwa dalam masa yang sulit terdapat bagian dari masyarakat Indonesia yang malah 
Tabel 3. Satir mengenai Bandit

\begin{tabular}{llc}
\hline \multicolumn{1}{c}{ Narasi Novel tentang Bandit dan Rampok } & \multicolumn{1}{c}{ Unsur Satir } & Halaman \\
\hline $\begin{array}{l}\text { "Penduduk bekasi tak bisa melupakan betapa kejam } \\
\text { dan jahatnya barisan garong"..... }\end{array}$ & $\begin{array}{l}\text { Garong bentukan Belanda } \\
\text { yang hanya mengambil } \\
\text { keuntungan dalam } \\
\text { kekacauan revolusi }\end{array}$ & 5 \\
Kami polisi Cuma bersenjata empat kerabin. & $\begin{array}{l}\text { Polisi tidak berdaya } \\
\text { menghadapi kerabin }\end{array}$ & 68 \\
$\begin{array}{l}\text { Bagaimana bisa melawan garong-garong yang } \\
\text { bersenjata lengkap itu?" }\end{array}$ & \\
"terlalu sedikit itulah sebabnya kami tak bisa melawan \\
garong-garong itu., \\
$\begin{array}{l}\text { "...terdengar nyata oleh saya perampok-perampok itu } \\
\text { menggertak dengan kasar, }\end{array}$ & $\begin{array}{l}\text { Masyarakat tidak berdaya } \\
\text { Menghadapi garong } \\
\text { menghadapi garong }\end{array}$ & 68 \\
\hline
\end{tabular}

mencari keuntungan dengan menindas sesamanya dan mereka mau diperalat Belanda untuk tujuan politiknya.

Polisi republik termasuk tentara dan laskar kesulitan untuk mengatasi para garong tersebut dikarenakan persenjataan yang dimiliki lebih sederhana dibandingkan dengan para perampok yang bersenjata lengkap. Selain itu, jumlah perampok tersebut jauh lebih banyak dibanding petugas keamanan itu sendiri (Toer, 1995: 68). Sejarah awal kemunculan para rampok di Bekasi diuraikan juga di Novel Di Tepi Kali Bekasi. Mereka berasal dari suatu daerah bernama Cibarusa dan dijelaskan bahwa pada masa Belanda dan Jepang, yang dirampoknya itu adalah tentara Belanda dan jepang, bukan warga seki$\operatorname{tar}$ (Toer, 1995: 69).

\section{Revolusi dan Pengkhianatan}

Kekacauan selama revolusi kemerdekaan nampak pula pada banyaknya narasi tentang Pengkhianat dan mata mata Belanda. Novel menceritakan bagaimana para pejuang memburu orang yang dianggap mata-mata bahkan sebagian besar mereka dieksekusi tanpa melalui proses peradilan sebelumnya. Ironi yang muncul dari narasi para penghianat di novel, yaitu mereka yang mencari keuntungan dalam suasana tata terbit sosial yang hancur. Selain itu, narasi tentang pengkhianat dihubungkan oleh Pramoedya dengan konflik antar generasi (Farid dan ayahnya), masyarakat yang paranoid, tindakan brutal dan main hakim sendiri masyarakat, serta diangkatnya satu etnis tertentu yang dinilai banyak membela Belanda. Pada Tabel 4 ditunjukkan gaya bahasa satir mengenai Revolusi dan Pengkhianatan.

Pramoedya Ananta Toer mengambarkan nasib buruk para pengkhianat ditangan para pejuang revolusi ketika menceritakan jembatan kali bekasi yang disebutnya jembatan jagal (Toer, 1995:4). Belanda mempergunakan bagian pasar dan mengadu-domba Tionghoa dengan bangsa Indonesia dalam bidang perdagangan (Toer, 1995). Etnis Tionghoa dinarasikan dalam sudut pandang negatif karena mereka banyak menjadi tentara NICA yang banyak mengeksekusi pribumi. Namun, Pramoedya tidak selamanya berpandan- 


\section{Tabel 4. Satir mengenai Revolusi dan Pengkhianatan}

\begin{tabular}{|c|c|c|}
\hline Narasi Novel tentang Revolusi dan Pengkhianatan & Unsur Satir & Halaman \\
\hline $\begin{array}{l}\text { "Ia teringat kejadian kemarin. Seorang pemuda } \\
\text { menembak bapaknya, karena ternyata bapaknya } \\
\text { masuk NICA ... }\end{array}$ & $\begin{array}{l}\text { Pengkhianatan yang } \\
\text { menimbulkan masalah } \\
\text { dalam keluarga }\end{array}$ & 11 \\
\hline $\begin{array}{l}\text { wah itu penghianat kelas wahid, mata-mata musuh, } \\
\text { mata-mata Inggris di Cibening". }\end{array}$ & $\begin{array}{l}\text { Adanya pengkhianat dan } \\
\text { mata-mata }\end{array}$ & 46 \\
\hline $\begin{array}{l}\text { "Pantas! Mata-mata si. Sudah matikah ia?"'"Mati? } \\
\text { Kebal, tak mau mati, sundel benar! Mulai jam } \\
\text { setengah tujuh tadi sudah digebugi, wah-wah-wah, tak } \\
\text { sekalipun ia mengaduh..... }\end{array}$ & $\begin{array}{l}\text { Mata-mata yang dibantai } \\
\text { masayarakat }\end{array}$ & 46 \\
\hline $\begin{array}{l}\text { Kabarnya genting. Tukang-tukang beras membawa } \\
\text { berita bahwa NICA Tionghoa di Klender bersumbar- } \\
\text { sumbar, katanya pada hari Senin hidup orang } \\
\text { Indonesia tinggal sehari lagi!" }\end{array}$ & Nica Tionghoa & 176 \\
\hline
\end{tabular}

\section{Tabel 5. Satir mengenai Konflik Generasi}

\begin{tabular}{|c|c|c|}
\hline Narasi Novel tentang Konflik Generasi & Unsur Satir & Halaman \\
\hline $\begin{array}{l}\text { "Pemuda jaman sekarang, ". Keluhnya. "Bertempur.. } \\
\text { Menggempur.. Orang tuanya dikesisikan..... }\end{array}$ & $\begin{array}{l}\text { Anak berjuang, orangtua } \\
\text { tidak dipedulikan }\end{array}$ & 10 \\
\hline $\begin{array}{l}\text { "...Farid mengapa kamu tak mau bercakap-cakap } \\
\text { denganku? Rintih bapaknya...” } \\
\text { “...”Ini, saya sudah bicara. Saya harus berangkat! } \\
\text { Harus. Doakan selamat saya menjalankan kewajiban } \\
\text { saya, bapak!...” }\end{array}$ & Konflik ayah dan anak & 10 \\
\hline $\begin{array}{l}\text { “...dalam berjalan itu ia berpendapat bahwa nasib } \\
\text { bapaknya seakan-akan telah direncanakan oleh NICA. } \\
\text { Ia digedor, dimelaratkan. Kemudian masuk NICA } \\
\text { supaya anaknya bisa tertangkap ...... }\end{array}$ & $\begin{array}{l}\text { Ayah pekerja NICA, anak } \\
\text { pejuang berperang melawan } \\
\text { NICA }\end{array}$ & 92 \\
\hline
\end{tabular}

gan negatif terhadap Tionghoa. Dalam kajian Niekerk (2017) mengenai novel Gadis Pantai, Pramoedya menilai bahwa etnis Cina telah lama menjadi bagian integral masyarakat Indonesia dan mereka belum diperlakukan secara adil.

\section{Konflik Generasi}

Novel menguraikan pula konflik antar generasi masa Revolusi. Selama masa revolusi, konflik tidak hanya terjadi antara Indonesia dengan Belanda, melainkan juga sesama anak bangsa, termasuk generasi tua dan muda, pro Belanda dengan pro Republik. Dalam karya Pramoedya, konflik antarangkatan cukup dominan (Teeuw, 1995: 39). Tabel 5 memperlihatkan gaya bahasa satir mengenai konflik generasi.

\section{Nasionalisme dan Pemuda}

Novel banyak mengambarkan semangat revolusioner para pemuda dalam membela bangsanya dan bagaimana masyarakat memotivasi para pejuang untuk terus memiliki semangat juang. Semangat revolusioner inilah yang 
Tabel 6. Satir mengenai Nasionalisme Pemuda

\begin{tabular}{llc}
\hline \multicolumn{1}{c}{ Narasi Novel tentang Nasionalisme Pemuda } & \multicolumn{1}{c}{ Unsur Satir } & Halaman \\
\hline "Memang, sayang sekali", "Apa programmu & $\begin{array}{l}\text { Semangat Nasionalisme } \\
\text { tinggi namun ekonomi } \\
\text { sekarang?" }\end{array}$ & 16 \\
"Nggak punya. Saya si emang ingin maju, tapi orang & kacau \\
tua nggak bisa mengongkosi bagaimana? Saya sendiri & \\
klimpungan..... & Prajurit dari Resimen & 125 \\
"Sepanjang jalan mereka menyanyikan berbagai & $\begin{array}{l}\text { Cikampek boleh dikata } \\
\text { berasal dari Jakarta } \\
\text { lagu riang gembira, lagu perjuangan yang berapi-api. } \\
\text { Terutama lagu "Maju Perang" ... }\end{array}$ & $\begin{array}{l}\text { pegawai, orang lontang- } \\
\text { lantung, orang agama, }\end{array}$ \\
& bajingan, evacuee \\
\hline
\end{tabular}

menjadi inti dari novel ini. Pramoedya merekam bangkitnya revolusi jiwa: awal mula pemuda bersedia mempertaruhkan nyawa untuk keadilan sosial dan martabat manusia (Toer, 1995: v). Pada Tabel 6 ditunjukkan gaya bahasa satir mengenai nasionalisme dan pemuda.

Pramoedya menguraikan panjang lebar mengenai semangat para pemuda yang menjadi laskar (Teor, 1995: 16). Dalam novel dijelaskan mengenai kebiasaan tentara menyanyikan lagulagu yang membangkitkan semangat juang (Toer, 1995: 125). Pramoedya menyebutkan bahwa salah satu lagu penyemangat yang sering dinyanyikan pemuda adalah Darah Rakyat. Novel memungkinkan Pramoedya menciptakan tokoh-tokoh terkarakter kuat yang dihidupkan dengan beragam wujud emosi yang tak terdokumentasikan dalam buku-buku sejarah umumnya (Farid, 2008: 68).

Pemuda yang ikut berperang merupakan pemuda yang tidak semuanya mempunyai jiwa yang militan karena baru kembali dari bahaya kelaparan serta tidak mempunyai pengalaman kemiliteran. Novel menceritakan per- juangan pemuda Indonesia selama satu setengah tahun di front Jakarta Timur pada bulan Oktober 1945 walaupun dengan kondisi hampir semua pemudanya tidak tahu cara menembak, mereka belajar menembak pada saat terjadi pertempuran (Gunawan, 2017: 520). Semangat revolusioner para pemuda nampak pada dialog-dialog di novel serta nampak pada panggilan antar pejuang, yaitu sebutan "Bung" (Toer, 1995: 16).

Gaya satir Pramoedya memang unik, ketika sedang menceritakan semangat patriotisme tinggi dari para pemuda, diselipkan hal yang membuat pembaca jadi terheran-heran dan bertanya karena penulis menceritakan hal positif namun negatif sekaligus. Bagaimana tidak, narasi patriotisme diringi oleh uraian bahwa tidak semua tentara memiliki militansi karena ada yang menjadi tentara untuk menghindari kelaparan, menjadi tentara agar dapat disukai para gadis, dan terkesan gagah karena menenteng senjata kemana-mana, serta menjadi tentara namun belum cukup bekal pelatihan dasar karena sebagian besar belum bisa 
menembak. Di novel disebutkan bahwa granat ditukarkan dengan durian (Toer, 1995: 14). Inilah sebuah ironi dalam revolusi Indonesia, pemuda merampas senjata dari Jepang, dan menukarkan senjata dengan makanan. Nampaknya Pramoedya ingin mengatakan kepada pembaca bahwa kita belum siap dengan revolusi.

\begin{abstract}
Moral Tentara
Salah satu kelebihan novel ini adalah pembaca banyak diberikan informasi yang lengkap dan detail tentang keadaan tentara Indonesia. Keadaan markas tentara Indonesia diuraikan secara detail oleh pengarang. Markas tentara Indonesia di daerah pertempuran sekitar Bekasi dan Cikampek itu sangat sederhana (Toer, 1995:63). Ta-
\end{abstract}

\section{Tabel 7. Satir mengenai Moral Prajurit}

\begin{tabular}{|c|c|c|}
\hline Narasi Novel tentang Moral Tentara & Unsur Satir & Halaman \\
\hline $\begin{array}{l}\text { "... prajurit Peta tidak hanya harus berhati-hati } \\
\text { terhadap gerakan lawannya yang seperti ular kecil ... } \\
\text { tetapi juga malaria" }\end{array}$ & $\begin{array}{l}\text { Musuh tentara bukan hanya } \\
\text { Inggris dan NICA, namun } \\
\text { juga Malaria }\end{array}$ & 2 \\
\hline $\begin{array}{l}\text { "Sayang sekali, tindakan prajurit-prajurit wanita yang } \\
\text { kasar itu menimbulkan pengaruh yang kurang baik } \\
\text { dikalangan rakyat ..." }\end{array}$ & $\begin{array}{l}\text { prajurit-prajurit wanita yang } \\
\text { berprilaku kasar kepada } \\
\text { masyarakat }\end{array}$ & 22 \\
\hline $\begin{array}{l}\text { "Surip sejak tadi merundukkan kepala tak juga } \\
\text { ditegakkan. Barangkali sedang membanding- } \\
\text { bandingkan jasa Amir dengan kecurangannya selama } \\
\text { bekerja di keuangan..." }\end{array}$ & $\begin{array}{l}\text { Surip dan perilaku korupsi } \\
\text { di Tentara }\end{array}$ & 52 \\
\hline $\begin{array}{l}\text { "Amir telah gugur! Amir yang gagah perwira. } \\
\text { Berkorban untuk pertiwi Indonesia...." }\end{array}$ & $\begin{array}{l}\text { Amir, symbol prajurit } \\
\text { idelais dan jujur, namun } \\
\text { cepat gugur }\end{array}$ & 51 \\
\hline $\begin{array}{l}\text { "Farid dan regunya sibuk membereskan tangsi baru. } \\
\text { Sebentar-sebentar ia membentak juru masak yang } \\
\text { bermata satu, kurang cepat menyediakan air coklat } \\
\text { untuk pagi hari" }\end{array}$ & $\begin{array}{l}\text { Perilaku kasar prajurit } \\
\text { Indonesia pada juru masak }\end{array}$ & 65 \\
\hline $\begin{array}{l}\text { "Pemeriksaan di Kranji kerap memaksa mereka tidur } \\
\text { di pasar, di depan toko atau warung, di rumah-rumah } \\
\text { penduduk. Kesempatan inilah yang dipergunakan } \\
\text { oleh prajurit-prajurit ...untuk memuaskan hawa } \\
\text { nafsunya. Moril bejat oleh tukang beras. Mereka } \\
\text { rela memberikan dagingnya asal bisa mendapat } \\
\text { penginapan dan air mandi yang layak" }\end{array}$ & $\begin{array}{l}\text { Moril bejat oleh tukang } \\
\text { beras. Mereka rela } \\
\text { memberikan dagingnya asal } \\
\text { bisa mendapat penginapan } \\
\text { dan air mandi yang layak. }\end{array}$ & 128 \\
\hline $\begin{array}{l}\text { "Di Wagon, di selokan, di pasar, di stasiun. Pikiran } \\
\text { yang tidak sehat ...... tetapi kebutuhan memaksa - } \\
\text { kebutuhan manusia yang mempunyai jenis laki-laki. } \\
\text { Mereka tidak rugi malah untung mendapat upah duit, } \\
\text { sigaret luar negeri, korned, dan sebagainya" }\end{array}$ & Perilaku bejat prajurit & 129 \\
\hline $\begin{array}{l}\text { "...Jam lima pagi! Prajurit-prajurit masih tidur. Dingin } \\
\text { betul..." }\end{array}$ & Prajurit tidak disiplin & 156 \\
\hline $\begin{array}{l}\text { "Kecewa betul saya ini, Surip! Kranji-Bekasi jatuh, } \\
\text { rasanya seluruh Jawa Baratlah yang tuntuh. Ah, saya } \\
\text { minta keluar saja..." }\end{array}$ & Kekecewaan Prajurit & 203 \\
\hline
\end{tabular}


bel 7 memperlihatkan gaya bahasa satir mengenai moral prajurit.

Novel mendeskripsikan kondisi prajurit yang mengkawatirkan dengan peluru yang terbatas,proses pendaftaran menjadi tentara, bagaimana mereka berlatih, dan bagaimana mereka melaksanakan tugas dalam satuan-satuan kecil. Hal tersebut sering tidak ternarasikan dalam buku teks karya sejarawan. Novel menjelaskan tentang bagaimana perubahan nama TKR yang menimbulkan kegundahan dan kegaduhan. Kegundahan dan kegaduhan terjadi karena dampak dari perubahan nama TKR, terjadi kenaikan dan penurunan pangkat yang massal dan tidak jelas. Hal tersebut jelas membuat sebagian prajurit merasa kecewa dengan kebijakan tersebut (Toer, 1995: 39).

Perilaku keseharian tentara juga dinarasikan dengan detail oleh Pramoedya. Tentara yang protes ke tukang dapur karena masakannya yang tidak memuaskan, tukang cuci piring yang kerjaannya tidak beres dan tidak bersih serta lain sebagainya (Toer, 1995: 65). Dalam novel dijelaskan mengenai budaya makan tentara saat itu yang tak karuan. Selain cara makan yang tidak sesuai adat, novel juga menjelaskan tentang kondisi makanan prajurit republik yang buruk karena penuh krikil (Toer, 1995: 32).

Di beberapa bagian novel, Pramoedya menyelipkan gambaran perempuan Indonesia pada waktu itu, termasuk yang menjadi tentara. Gambaran tentara perempuan memang kurang baik karena mereka disebut berperangai kasar dan bersikap ekstrim, sehingga menimbulkan citra kurang baik tentara di mata masyarakat. Namun demikian mereka terkenal jeli dan jago menang- kap mata-mata NICA maupun Inggris. Pramoedya juga memberikan informasi bahwa pedagang-pedagang beras di pasar-pasar di Bekasi mayoritas adalah perempuan (Toer, 1995: 22).

Selain itu, gambaran tentang para pejuang Indonesia yang kurang baik secara moral diuraikan juga oleh novel $D i$ Tepi Kali Bekasi. Pramoedya menjelaskan tentang prajurit yang suka memanfaatkan di sela tugas mereka dengan mendatangani para pelacur untuk memuaskan nafsunya. Pramoedya menilai perilaku tersebut hanya menimbulkan penyakit kotor di tengah masyarakat. Pramoedya menuliskan juga tentang karakter prajurit republik yang pemalas. Perilaku moral yang bejat dinarasikan juga ketika menceritakan pertempuran di Bekasi dimana prajurit Indonesia memergoki sepasang pemuda pemudi yang berbuat mesum di gedung yang kosong. Inilah ironi revolusi yang digambarkan oleh Pramoedya karena revolusi tidak sesakral yang para pembaca bayangkan selama ini.

Karakter-karakter manusia masa revolusi tergambar pada tokoh-tokoh utama dalam novel ini, seperti Farid, Amir, Soerip, dan Nanny. Tokoh-tokoh tersebut juga mewakili ironi dalam revolusi termasuk juga bagian dari kritikan Pramoedya pada situasi sosial poltik masa revolusi. Salah satu motif pemuda menjadi tentara adalah karena faktor ekonomi. Surip yang digambarkan memiliki karakter anak yang penakut masuk tentara bukan karena hendak berjuang membentengi rakyat, melainkan untuk mencari makan dan pakaian serta mencari tempat yang lebih aman daripada Jakarta (Toer, 1995: 21). 
Surip digambarkan sebagai seorang yang berpendidikan dan tinggi harga dirinya (Toer, 1995: 37). Selama menjadi tentara memiliki pangkat dan kedudukan yang baik, karena bekerja di bagian keuangan. Semenjak bekerja di keuangan, Surip mulai memelihara badannya walaupun tidak pernah turut latihan (Toer, 1995: 48). Namun diakhir cerita, Surip mengalami kebangkrutan karena dikeluarkan dari posisinya dibagian keuangan. Tindakan korupsi inilah yang menyebabkan Surip terlempar dari posisinya tersebut (Toer, 1995: hal. 168).

Amir yang pada masa Jepang sudah mendapat pengalaman militer, cepat dikirim ke garis depan dan gugur dalam aksi yang berani. Amir digambarkan sebagai sosok ideal tentara, tidak pengecut, jauh dari perilaku amoral, dan siap mengorbankan jiwanya demi negara (Toer, 1995: 54). Nama Amir mulai harum, dihormati oleh semua prajurit. Pangkatnya cepat naik menjadi letnan dua. Keharumannya tak berfaedah bagi dirinya sendiri karena keluarga yang ditinggalkannya di Jakarta dibunuh sekutu (Toer, 1995: 49).

Dalam roman ini, Nanny memenuhi peran sebagai hati nurani Farid. Novel menceritakan tentang romantisme, drama percintaan ditengah berkecamuknya perang. Romantisme nampak pada hubungan antara pemuda dan pemudi, Cinta segitiga antara Farid dan Soerip dengan gadis Nanny. Persahabatan mereka dikomplikasikan oleh kehadiran Nanny, gadis Indo yang mati kedua orang tuanya dan memihak pada Republik. Bagi Nanny, Farid memang pemuda ideal, pahlawan patriotik yang dalam hatinya mengambil tempat Amir almarhum. Dan bagi Farid, Nanny juga perempuan ideal, mungkin malahan sebagai pengejawantahan Indonesia. Novel juga sepintas menceritakan percintaan antara tentara republik dengan gadis-gadis di sekitar markas tentara.

\section{Pembahasan \\ Satir dan Cara Pandang Prameodya ten- tang Revolusi Indonesia}

Dalam pandangan sosiologi sastra, seorang sastrawan tidak hidup dalam ruangan kosong. Karya-karya seorang novelis akan dipengaruhi oleh jalinan unsur-unsur sosial yang ada, nilai-nilai yang dianutnya termasuk cara pandangnya terhadap realitas. Dengan demikian, pemahaman mengenai novelis $\mathrm{cu}-$ kup penting dalam menganalisis novel. Hertz (2008) mengungkapkan bahwa penulis novel sejarah yang baik berusaha mencipta ulang masa lalu maupun memberikan penjelasan sejarah dengan tidak tergesa-gesa dan tidak juga berupa fiksi murni. Dengan demikian, novelis juga memiliki cara pandang dalam menjelaskan realitas yang digambarkan dalam novelnya.

Bagaimana cara pandang Pramoedya mengenai revolusi Indonesia dalam novel Di Tepi Kali Bekasi? Terlebih dahulu ditunjukkan pandangan satirnya dalam novel tersebut sebagaimana terlihat pada Tabel 8 .

Pesan satir dalam novel Di Tepi Kali Bekasi ini setidaknya mengangkat dua hal penting, yaitu ironi dalam masyarakat dan tentara selama periode revolusi fisik 1945-1949 serta kritikan terhadap perilaku elite, masyarakat, dan tentara selama periode revolusi tersebut. Ironi dalam tentara diidentifikasi dari motif mereka gabung ketentara dan perilaku buruk mereka yang amoral. Sementara ironi yang terjadi 
Tabel 8. Tipologi Satir dalam Novel Di Tepi Kali Bekasi

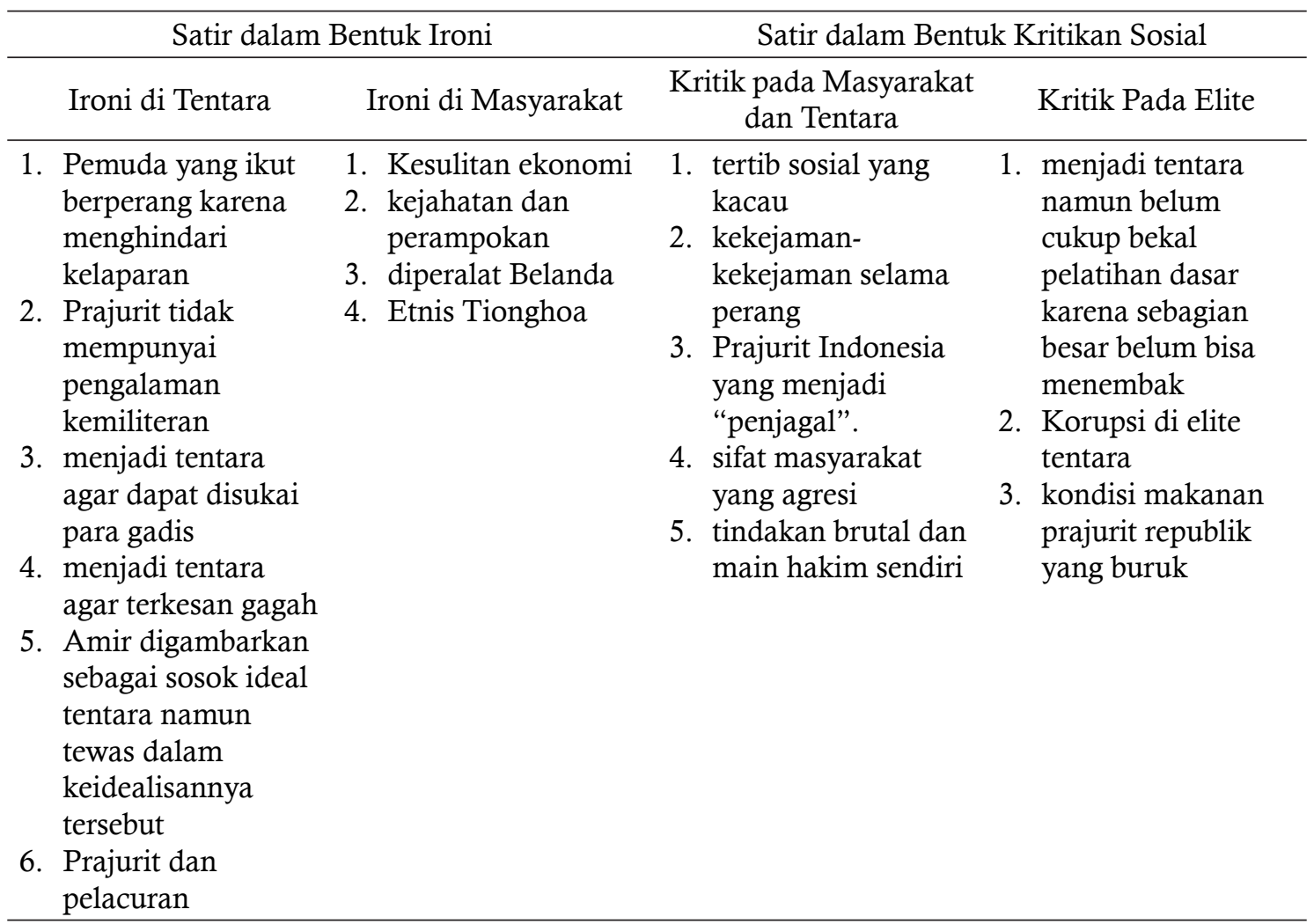

di masyarakat adalah kesulitan hidup yang muncul selama revolusi dan perilaku sebagian masyarakat yang mencari keuntungan ditengah revolusi tersebut dengan menjadi rampok atau menjadi kaki tangan Belanda.

Kritikan sosial ditujukan pada elite yang mengatur kehidupan tentara. Kondisi tentara yang kesulitan peluru, makanan yang buruk, dan korupsi para petinggi militer serta perilaku sebagian tentara yang bertindak kejam juga. Masyarakat dikritik Pramoedya karena paranoid dan berperilaku agresi sehingga bertindak brutal dan main hakim sendiri selama revolusi. Dari uraian tersebut, maka dapat disimpulkan bahwa Pramoedya menggunakan satir juvenalian. Satire juvenalian adalah satire yang nadanya getir dan agresif yang memperlihatkan kerusakan moral menggunakan sarkasme, parodi, dan teknik sejenis untuk memperlihatkan betapa rusaknya sesuatu.

Novelis mengkonstruksi budaya suatu masyarakat melalui karya sastranya. Setiap novelis memotret dan memaknai kehidupan di sekitarnya untuk kemudian diekspresikan melalui karya sastra. Cara pandang Pramoedya mengenai revolusi secara singkat digambarkan di Tabel 9.

Pramoedya menyebut masa revolusi sebagai zaman kebinatangan (Teeuw, 1995: 12). Kemarahan pada pengkhianat nampak pada karangan Pamoedya ini. Hal itu terlihatpada saat Farid menemukan ayahnya telah masuk kerja kembali dengan tentara Belanda dan telah masuk NICA, amarahnya me- 


\section{Tabel 9. Pandangan Pramoedya tentang Revolusi Indonesia}

\begin{tabular}{|c|c|c|}
\hline No. & $\begin{array}{c}\text { Pandangan Pramoedya tentang } \\
\text { revolusi }\end{array}$ & Point di Novel \\
\hline 1 & $\begin{array}{l}\text { Revolusi sebagai zaman } \\
\text { kebinatangan }\end{array}$ & $\begin{array}{l}\text { 1. situasi tertib sosial yang kacau } \\
\text { 2. masyarakat Bekasi yang paranoid } \\
\text { 3. kejahatan dan perampokan di Jakarta dan sekitarnya } \\
\text { 4. kekejaman-kekejaman selama perang } \\
\text { 5. Prajurit Indonesia yang dibanggakan juga ternyata bisa } \\
\text { menjadi "penjagal". } \\
\text { 6. revolusi hanya melahirkan sifat masyarakat yang agresi } \\
\text { 7. polisi dan masyarakat "tidak berdaya" menghadapi } \\
\text { rampok } \\
\text { 8. tindakan brutal dan main hakim sendiri masyarakat } \\
\text { 9. para pemuda mendapatkan senjata dari hasil rampasan } \\
\text { tentara Jepang dan Sekutu } \\
\text { 10. konflik antar generasi }\end{array}$ \\
\hline 2 & $\begin{array}{l}\text { Revolusi jiwa lebih berhasil } \\
\text { daripada revolusi besenjata }\end{array}$ & $\begin{array}{l}\text { 1. semangat revolusioner para pemuda dalam membela } \\
\text { bangsanya } \\
\text { 2. semangat pemuda dalam menegakkan keadilan dan } \\
\text { martabat demi meraih kebebasan }\end{array}$ \\
\hline 3 & $\begin{array}{l}\text { Kemerdekaan hanya } \\
\text { kemerdekaan semu dan sia-sia }\end{array}$ & $\begin{array}{l}\text { 1. terdapat bagian dari masyarakat Indonesia yang malah } \\
\text { mencari keuntungan dengan menindas sesamanya. } \\
\text { 2. Masyarakat bawah tidak diuntungkan dalam revolusi }\end{array}$ \\
\hline 4 & Suara kaum subaltern & $\begin{array}{l}\text { 1. Kesulitan ekonomi } \\
\text { 2. Perempuan penjual beras } \\
\text { 3. Prajurit berpangkat rendah } \\
\text { 4. Kegundahan dan kegaduhan terjadi karena dampak } \\
\text { dari perubahan nama TKR } \\
\text { 5. budaya makan tentara saat itu yang tak karuan. } \\
\text { 6. cara makan tentara yang tidak sesuai adat, } \\
\text { 7. kondisi makanan prajurit republik yang buruk karena } \\
\text { penuh krikil }\end{array}$ \\
\hline 5 & $\begin{array}{l}\text { Kehancuran moral, Korupsi } \\
\text { dan pengkhianatan }\end{array}$ & $\begin{array}{l}\text { 1. Etnis Tionghoa banyak menjadi tentara NICA } \\
\text { 2. Bandit dan rampok } \\
\text { 3. Ayah Farid bekerja di kantor NICA } \\
\text { 4. prajurit yang suka memanfaatkan di sela tugas mereka } \\
\text { dengan mendatangani para pelacur } \\
\text { 5. memergoki sepasang pemuda pemudi yang berbuat } \\
\text { mesum di gedung yang kosong } \\
\text { 6. Tindakan korupsi yang menyebabkan Surip terlempar } \\
\text { dari posisinya }\end{array}$ \\
\hline
\end{tabular}

luap-luap, dan ia mengutuk Jakarta, yang ketularan penyakit kolonial (Teor, 1995: 142-143). Revolusi sebagai zaman edan digambarkan dalam kehancuran ekonomi dan kemelaratan masyarakat, norma sosial yang ambruk, masyarakat yang paranoid, brutal dan main hakim sendiri, rampok yang merajalela, kekejaman perang, dan konflik antar generasi.

Melalui karakter tokoh-tokohnya, novel menggambarkan banyak hal se- 
perti peran Amir sebagai sosok tentara dan pahlawan teladan; konflik Farid dan ayahnya (konflik generasi); konflik Farid dengan Soerip yang sementara waktu melupakan cita-cita revolusi dan hanya mengejar kesenangannya sendiri; hubungan Farid dengan Nanny yang kesuciannya harus dipertahankan demi kemurnian cita-cita revolusi; kekecewaan Farid atas korupsi dan kepengecutan yang disaksikannya dalam tentara dan kemarahannya ketika ia melihat seorang nenek yang kehilangan cucunya, serta Inggris yang membakar kampungnya. Belas kasihan yang dirasakan Farid atas penderitaan rakyat yang terpaksa mengungsi sebagai akibat perang yang ganas (Teeuw, 1995: hal 24-25).

Pramoedya berpendapat bahwa revolusi jiwa lebih berhasil daripada revolusi bersenjata dan disebut sebagai ideologi pemuda. Mungkin bagian inilah yang merupakan sisi positif yang diangkat pada revolusi Indonesia. Penokohan yang digambarkan melalui Farid, seorang pemuda yang gelisah dengan kondisi bangsanya, kecewa karena ayahnya mantan KNIL sehingga mempunyai keyakinan, jika dirinya turun ikut berjuang, akan menyelamatkan martabat keluarga dan negaranya.

Bagi Pramoedya, revolusi sebenarnya gagal dan kemerdekaan hanya kemerdekaan semu dan sia-sia, sebab yang menikmati hasil perjuangan rakyat hanya kalangan kecil, politisi dan orang kaya sedangkan rakyat sendiri makin menderita (Teeuw, 1995). Pramoedya banyak mengangkat isuisu seperti persamaan atau egaliter dan coba mengangkat suara kaum subaltern, kritikus ketidakadilan sosial, pentingnya mencerdaskan anak bangsa, menjunjung tinggi demokrasi, dan cinta tanah air. Pramoedya banyak membahas kehidupan wong cilik dan mencoba mengangkat kehidupan mereka yang terkesan terabaikan.

Pesan moral Pramoedya pada generasi muda adalah kaum muda harus mampu menjalankan roda pemerintahan dengan bersih, bebas dari segala bentuk korupsi, kolusi dan nepotisme. Menurutnya, korupsi bukan hanya fenomena individu tapi merupakan masalah sosial politik. Tema korupsi juga menjadi bagian yang diekploitasi pada novel Pramodya yang lain, yaitu Korupsi (1954). Dalam kajian Niekerk (2017), Novel Korupsi menggambarkan kehidupan pemerintahan yang korup selama era Soekarno.

Gambaran masyarakat yang sempurna menurut Pramoedya adalah masyarakat yang demokratis, emansipasi perempuan, dan tidak ada penindasan. Dalam novel Korupsi, Pramoedya membuat satir dengan mengaitkan poligami dengan kemakmuran ekonomidan keberhasilan masyarakat, meskipun keberhasilan dibangun di atas perilaku korup(Niekerk, 2017).Gambaran perempuan sebagai korban strukur sosial yang tertindasakan banyak ditemukan dalam novel-novel Pramoedya. Di Keluarga Geriliya, Ratni adalah seorang pengungsitanpa rumah, dan Amilah berserta putri-putrinya hidup dalam kemiskinan. Gambaran tersebut dapat ditemukan juga dalam novel Gadis Pantaidan Larasati. Gadis Pantai adalah kritik Pramoedya terhadap kolonialisme Belanda dan feodalisme dengan mengungkap penghinaan elit untuk kelas sosial dan pernikahan, Larasati adalah gagasan Pramoedya bahwa satu-satunya cara yang bisa didapatkan seorang perempuan agar mendapat perhatian 
utama adalah melalui seksualitasnya (Dewi, 2007).

Di Tepi Kali Bekasi jelas terlihat bahwa garapan Prameodya tidak terletak pada prestasi militer atau kemampuan berperang pada pemuda kita kebanyakan. Tetapi, dari front Bekasi Pramoedya merekam bangkitnya revolusi jiwa: awal mula pemuda bersedia mempertaruhkan nyawa untuk keadilan sosial dan martabat manusia, permulaan rakyat berani berhenti manut menghamba pada majikan kolonial dan meraih kebebasan jiwa. Revolusi inilah menurutnya jauh lebih berhasil daripada revolusi bersenjata.

Aspek seksualitas dan perilaku amoral tentara yang digambarkan $D i$ Tepi Kali Bekasi merupakan aspek yang juga dinarasikan di Novel Pramoedya yang lain, yaitu Keluarga Geriliya. Baik Di Tepi Kali Bekasi maupaun Keluarga Geriliya memiliki suara yang sama, yaitu masalah-masalah seksual mengalihkan perhatian dari tujuan-tujuan revolusi dan dikaitkan dengan dekadensi dan kemunduran masyarakat (Niekerk, 2017).

\section{Akar Satirdalam Novel Di Tepi Kali Bekasi}

Menurut kajian Teeuw (1995), roman ini bertumpuan pada pengalaman pribadi pengarang yang disusun pada tahun 1959, khususnya mengenai masa antara Oktober 1945-Juli 1946. Dengan demikian, setting waktu dan tempat menurut analisa Teeuw (1995) adalah nyata dan fakta yang didasarkan pada pengalaman pribadi Pramoedya. Pramoedya memang pernah menjadi tentara yang bertugas di Cikampek sebagai perwira penghubung. Cikampek merupakan front pertahanan pejuang Indonesia, sedangkan Bekasi menjadi front terdepannya yang dibatasi oleh Kali Bekasi dengan bagian timur dikuasai tentara Indonesia dan bagian barat Sentara Sekutu.

Dari data-data yang telah disusun sebelumnya, dapat disimpulkan bahwa akar satir dalam novel Di Tepi Kali Bekasi bertumpu pada dua hal, yaitu pengalaman langsung Pramoedya sebagai tentara dan gagasan-gagasan yang ingin disampaikannya dalam novel. Pramoedya memiliki pengalaman langsung dalam peristiwa Cikampek, walau

Tabel 10. Akar Satir Pramoedya Ananta Toer

Akar Satire di Novel Tepi Kali Bekasi

\begin{tabular}{|c|c|}
\hline $\begin{array}{c}\text { Pengalaman langsung Pramoedya sebagai } \\
\text { Tentara }\end{array}$ & Gagasan Pramoedya \\
\hline $\begin{array}{l}\text { 1. kekecewaan yang mendalam karena } \\
\text { jatuhnya Bekasi } \\
\text { 2. frustrasi atas hal-hal yang dilihatnya } \\
\text { dalam tentara } \\
\text { 3. terharu melihat kesengsaraan rakyat yang } \\
\text { menjadi korban perang } \\
\text { 4. konflik antar generasi }\end{array}$ & $\begin{array}{l}\text { 1. tidak pernah mabuk heroisme atau suka } \\
\text { menggembar- gemborkan kecemerlangan hasil } \\
\text { perjuangan prajurit Indonesia } \\
\text { 2. tertarik pada aspek moral perjuangan, pada } \\
\text { keadilan dan kemanusiaan } \\
\text { 3. melawan penindasan dan kebodohan } \\
\text { 4. tujuan utama perjuangan adalah membebaskan } \\
\text { rakyat dari ketakutan dan kesengsaraan } \\
\text { 5. gagasan-gagasan untuk dipikirkan } \\
\text { 6. memulihkan kesadaran sejarah Indonesia }\end{array}$ \\
\hline
\end{tabular}


tidak sampai tahun 1949 karena kecewa dengan korupsi yang terjadi di satuannya (Gunawan, 2017: 525).

Pramoedya Ananta Toer langsung terlibat dalam peperangan di masa Revolusi dan ditempatkan di Kranji dan Bekasi. Bagi Pramoedya Ananta Toer, dua tempat itu mempunyai arti tersendiri sehingga mampu mewujudkan bakat dan cita-citanya. (Gunawan, 2017: hal 523). Namun jelas pula berita pengalaman Pramoedya berlainan dengan cerita pengalaman tokoh utamanya, Farid (Teeuw, 1995). Tokoh Farid diidentikan dengan Pramoedya sendiri karena beberapa hal. Selain latar belakang pendidikan yang sama dengan Pram, juga uraian uraian di novel mengenai kondisi Farid di tentara (Toer, 1995: 26). Pada bulan Oktober 1945 , Pramodya menjadi anggota pasukan Badan Keamanan Rakyat dan ditempatkan di Cikampek dalam kesatuan Banteng Taruna (resimen 6) yang beroperasi di Jakarta Timur, yang kemudian menjadi pusat bagian Siliwangi, sebagai prajurit II. Dalam waktu singkat ia naik pangkat menjadi "sersan mayor".Jatuhnya Bekasi meninggalkan kekecewaan yang mendalam di dada para prajurit termasuk Pramoedya sendiri. Perjuangan mereka mati-matian mempertahankan Bekasi tak cukup karena persenjataan dan teknologi perang yang jauh tertinggal.

Novel di Tepi Kali Bekasi memperlihatkan Pramoedya sudah cukup dini mengalami rasa frustrasi atas hal-hal yang dilihatnya dalam tentara, khususnya pergelutan merebut kekuasaan dan ketidakadilan sosial terutama korupsi yang pada masa itu nampaknya merajalela di kalangan tertentu. Oleh sebab itu, ia sendiri meninggalkan tentara pada akhir 1946, kemudian melanjutkan perannya dalam revolusi di bidang penerbitan dan radio. Rasa frustrasi itu juga diungkapkannya dalam berbagai karya-karyanya termasuk novel Di Tepi Kali Bekasi(Teeuw, 1995).

Pramoedya sebagai sastrawan tidak pernah mabuk heroisme atau suka menggembar-gemborkan kecemerlangan hasil perjuangan prajurit Indonesia. Ia jauh lebih tertarik pada aspek moral perjuangan, pada keadilan dan kemanusiaan, dan sudah amat dini ia cemas tentang korupsi dan ketamakan yang diperhatikannya di mana-mana. Konsep tentang kegagalan revolusi cukup awal mulai tampak dalam cerita-ceritanya (Teeuw, 1995).

Konflik generasi antara Farid dan ayahnya merupakan gambaran hubungan rumit antara Pramoedya dan ayahnya sendiri (Rangkuti, 1963; Bostock, 2017). Kekecewaan mendalam kepada ayahnya salah satunya disebabkan oleh keinginan ayahya agar Pramoedya tidak naik kelas, tetap di SD, dan tidak berhak melanjutkan ke MULO (Setingkat SMP). Pramoedya sangat terkejut oleh keputusan ayahnya untuk bekerja kepada Belanda pada awal 1940-an, sehingga hal tersebut membuatnya meragukan komitmen nasionalis ayahnya (Bostock, 2017). Hal tersebut nampak mirip dengan cerita Farid dan Ayahnya pada novel Di Tepi Kali Bekasi.

Karya Pramoedya Ananta Toer banyak menceritakan sejarah Indonesia yang berbeda, dengan bahasa yang jujur dan apa adanya. Pramoedya Ananta Toer tidak peduli apakah orang memahami karyanya atau tidak, akan tersinggung atau justru menyukai. Penggambaran perjuangan dalam karya Pramoedya Ananta Toer adalah 
melawan penindasan dan kebodohan, bagaimana cara memandang hidup seorang pribumi dan konflik-konflik pemikiran yang cenderung dipaparkan pada beberapa tokohnya (Gunawan, 2017).

Farid, sebagai penjelmaan ide-ide pengarang, selalu terharu melihat kesengsaraan rakyat yang menjadi korban perang, yang harus mengungsi dan meninggalkan rumah dan tanahnya, yang menderita kehilangan suami atau istri, anak atau kekasihnya, dan ia tahu bahwa pada hakekatnya itulah yang menjadi tujuan utama perjuangan: membebaskan rakyat dari ketakutan dan kesengsaraan. Sastra dalam pemikiran Pramoedya bertugas memberikan kepada pembacanya kata-kata dan gagasan-gagasan untuk dipikirkan sambil menunjukan jalan menuju masa depan yang lebih baik. Selain itu, bagi Pramoedya, motif penulisan novel ini adalah didorong oleh tekad untuk memulihkan orang-orang yang terpinggirkan sehingga dapat memulihkan kesadaran sejarah Indonesia.

\section{SIMPULAN}

Satir membantu kita dalam memahami keseluruhan novel Di Tepi Kali Bekasi. Dengan satir pula, pesan-pesan Pramoedya dapat ditangkap dan dipahami. Gambaran realitas sosial masa revolusi yang penuh ironi, dikritik dengan lugas oleh Pramoedya. Namun satir dalam novel ini ibarat obat yang pahit rasanya namun menyembuhkan. Satir diharapkan penulis dapat mengobatikebobrokan-kebobrokan sosialyang telanjang nyata ada di masyarakat.

Novel Di Tepi Kali Bekasi memberikan perspektif yang berbeda tentang sejarah. Pramoedya menggambarkan revolusi Indonesia dalam gaya bahasa satir yang penuh dengan kritikan tajam. Pesan satir dalam novel tersebut setidaknya mengangkat dua hal penting, yaitu ironi dalam masyarakat dan tentara selama periode revolusi fisik 1945-1949 serta kritikan terhadap perilaku masyarakat dan tentara.

Unsur satir yang dinarasikan dalamnovel ini antara lain terdapat dalam cerita kehancuran sosial beserta dampak-dampaknya, konflik antar generasi, semangat revolusioner para pemuda, serta perilaku korup dan amoral tentara dan masyarakat. Dengan gambaran seperti itu maka wajar saja Pramoedya menyebut masa revolusi sebagai zaman kebinatangan dan gagal. Bagi Pramoedya, kemerdekaan hanya kemerdekaan semu dan sia-sia dan yang berhasil hanyalah adanya revolusi mental pada para pemuda.

Namun, tidak hanya hal negatif saja yang diungkap Pramoedya karena dalam narasi satirnya, banyak mengangkat isu-isu seperti persamaan atau egaliter dan kehidupan wong cilik yang termarjinalkan. Pramoedya menggunakan satir juvenalian yang nadanya getir dan agresif yang memperlihatkan kerusakan moral. Harapan penulis, gambaran buruk ini menjadi bahan perbaikan terutama untuk generasi muda. Pramoedya tidak banyak berharap kepada golongan tua yang sudah terlalu terkontaminasi zaman dan sulit untuk berubah.

Akar satir dalam novelini bertumpu pada dua hal, yaitu pengalaman langsung Pramoedya sebagai tentara dan gagasan-gagasan yang ingin disampaikannya dalam novel. Menurut Pramoedya, revolusi adalah perjuangan untuk keadilan dan terbebas dari keta- 
kutan dan penindasan. Peristiwa dan pengalaman Farid dan rekan-rekannya diberikan makna yang jauh lebih luas, digeneralisasi menjadi peristiwa dan pengalaman rakyat Indonesia. Farid sadar, juga lewat pengalaman pribadinya, bahwa ikut serta dalam revolusi itu hanya mungkin kalau pada waktu yang sama selalu diperjuangkan kemanusiaan dalam dirinya, melawan godaan hawa nafsu.

\section{UCAPAN TERIMA KASIH}

Ucapan terima kasih disampaikan kepada Direktorat Riset dan Pengabdian Masyarakat Ristekdikti, Rektor cq Ketua LP2M Universitas Muhammadiyah Prof. Dr. Hamka (Uhamka) dan Universitas Pendidikan Indonesia yang telah memberi dukungan sehingga pelaksanaan penelitian dan penyusunan artikel ini dapat berjalan dengan lancar. Ucapan terima kasih juga disampaikan kepada bapak/ibu guru yang tergabung dalam MGMP Sejarah DKI Jakarta yang telah bersama-sama menggali novel Pramoedya dan mengunjungi jejak-jejak sejarah di Bekasi sampai Cikampek.

\section{DAFTAR PUSTAKA}

Aminuddin. (2009). Pengantar Apresiasi Karya Sastra. Bandung: Sinar baru Algesindo.

Aveling, H. (ed. and trans.). (1975). A note on the author. In $A$ heap of ashes by Pramoedya Ananta Toer. St Lucia: University of Queensland Press.

Bangsawan, A.R. (2017). Pramoedya Ananta Toer, Politik dan Sastra. Yogyakarta:Media Pressindo.

Bostock, D. (2017). Anehnja Hubungan Ajah dan Anak Ini, Indonesia and the
Malay World.45(131), 108-126, DOI: 10.1080/13639811.2017.1290895.

Dewi, N. (2007). Every Book Has a Voice: A Postcolonial Reading of Gadis Pantai and Larasati. Asian Englishes, 10:2, 82-91, DOI: 10.1080/13488678.2007.10801214.

Eriyanto. (2015). Analisis Isi: Pengantar Metodologi untuk Penelitian Ilmu Komunikasi dan Ilmu-Ilmu Sosial Lainnya. Jakarta: Prenadamedia Grup.

Eriyanto. (2013). Analisis Naratif: DasarDasar dan Penerapannya dalam Analisis Teks Berita Media. Jakarta: Prenadamedia Grup.

Farid, H. (2008). Pramoedya dan Historiografi Indonesia. Dalam buku "Perspektif Baru Penulisan Sejarah Indonesia. Jakarta: Yayasan Obor Indonesia.

Graf, A. (2007). 'Cyberpram': Perceptions of Pramoedya Ananta Toer on the Internet. Indonesia and the Malay World. 35(103), 293-312, DOI: $10.1080 / 13639810701676797$.

Gunawan, R. (2017). Kajian Heuristik Pada Novel Sejarah Pramoedya Ananta Toer. Dalam Margana Dkk (ed). Menemukan Historiografi Indonesiasentris. Yogyakarta: Ombak

Herriman. N. (2010). Objects of manipulation: the peopleand the rural village in Indonesia'sculture wars. South East Asia Research, 18(3),451470, doi: 10.5367/sear.2010.0003.

Hertz, S. K.(2018).Using Historical Fiction in The History Classroom.tersedia diwww.yale-newhaven.edu[online]. Diakses tanggal 15 April 2018.

Lindquist, T. (2008). Why and How I Teach with Historical Fiction. tersedia di httpwww.teacher.scholastic.com [online]. Diakses tanggal 15 Desember 2018. 
Murti, S.E. (2013). Peribahasa, Sastra Lama, dan Majas Plus Sinonim, Antonim, dan EYD. Jakarta: Mata Elang Media.

Niekerk, C. (2017). Colonial/Postcolonial Chronotopes in Pramoedya Ananta Toer's The Girl from the Coast. Symposium: A Quarterly Journal in Modern Literatures. 71:1, 1427.

Prasetyono, D.S. (2011). Buku Lengkap Majas dan Peribahasa. Yogyakarta: Diva Press.

Rangkuti, B. (1963). Pramoedya Ananta Toer dan Karja Seninja. Jakarta: Gunung Agung.

Raybin, D. (2009). Muslim Griselda: The Politics of Gender and Religion in Geoffrey Chaucer's Clerk's Tale and Pramoedya Ananta Toer's The Girl from the Coast. Exemplaria, 21:2, 179-200.
Ricklefs, M.C. (2005). Sejarah Indonesia Modern 1200-2004. Jakarta: PT Serambi Ilmu Semesta.

Teeuw, A. (1995).Revolusi Indonesia dalam Imajinasi Pramoedya Ananta Toer. Jurnal Kalam, 6, 4-47.

Teeuw, A. (1997). The ideology of nationalism in Pramoedya Ananta Toer's fiction. Indonesia and the Malay World, 25(73), 252-269, DOI: 10.1080/13639819708729903

Toer, P. A. (1995). Di Tepi Kali Bekasi. Jakarta : Hasta Mitra.

Tsao, T. (2012). The evolution of Javamen and Revolutionaries: A fresh look at Pramoedya Ananta Toer's BuruQuartet. South East Asia Research, 20(1), 103-131 doi: 10.5367/ sear.2012.0088.

Vickers, A. (2013). A History of Modern Indonesia. 2nd ed. Cambridge: Cambridge University Press. 